\title{
Categorizing the characteristics of human carcinogens: a need for specificity
}

\author{
Carr J. Smith ${ }^{1}$. Thomas A. Perfetti ${ }^{2}$. A. Wallace Hayes ${ }^{3}$. Sir Colin Berry ${ }^{4}$ James E. Trosko ${ }^{5}$. Judy A. King ${ }^{6}$. \\ Jay I. Goodman ${ }^{7}$. C. Glenn Begley ${ }^{8} \cdot$ Anthony Dayan $^{9}$
}

Received: 7 June 2021 / Accepted: 17 June 2021 / Published online: 20 June 2021

○ The Author(s), under exclusive licence to Springer-Verlag GmbH Germany, part of Springer Nature 2021

\begin{abstract}
The International Agency for Research on Cancer (IARC) has recently proposed employing "ten key characteristics of human carcinogens" (TKCs) to determine the potential of agents for harmful effects. The TKCs seem likely to confuse the unsatisfactory correlation from testing regimes that have ignored the differences evident when cellular changes are compared in short and long-lived species, with their very different stem cell and somatic cell phylogenies. The proposed characteristics are so broad that their use will lead to an increase in the current unacceptably high rate of false positives. It could be an informative experiment to take well-established approved therapeutics with well-known human safety profiles and test them against this new TKC paradigm. Cancers are initiated and driven by heritable and transient changes in gene expression, expand clonally, and progress via additional associated acquired mutations and epigenetic alterations that provide cells with an evolutionary advantage. The genotoxicity testing protocols currently employed and required by regulation, emphasize testing for the mutational potential of the test agent. Two-year, chronic rodent cancer bioassays are intended to test for the entire spectrum of carcinogenic transformation. The use of cytotoxic doses causing increased, sustained cell proliferation that facilitates accumulated genetic damage leads to a high false-positive rate of tumor induction. Current cancer hazard assessment protocols and weight-of-the-evidence analysis of agent-specific cancer risk align poorly with the pathogenesis of human carcinoma and so need modernization and improvement in ways suggested here.
\end{abstract}

Keywords Ten key characteristics of human carcinogens · TKC · International Agency for Research on Cancer · TKC broad and lack specificity $\cdot$ TKCs give high rate of false positives

Carr J. Smith

carr.smith@albemarle.com

1 Albemarle Corporation, 6400 Brindlewood Court, Mobile, AL 36608, USA

2 Perfetti and Perfetti, LLC, Winston-Salem, NC, USA

3 University of South Florida College of Public Health and Institute for Integrative Toxicology, Michigan State University, East Lansing, MI, USA

4 Queen Mary, London, UK

5 Department of Pediatrics and Human Development, Michigan State University, East Lansing, MI, USA

6 Department of Pathology and Translational Pathobiology, Louisiana State University Health Shreveport, Shreveport, LA, USA

7 Department of Pharmacology and Toxicology, Michigan State University, East Lansing, MI, USA

8 Independent Biotech Consultant, Victoria, AU, Australia

9 Royal College of Physicians, London, UK

\section{The breadth of the ten key characteristics of human carcinogens}

The International Agency for Research on Cancer (IARC) is employing a protocol for the initial evaluation of the carcinogenic potential of chemicals termed the ten key characteristics of human carcinogens (TKCs) (Smith et al. 2016; Bus 2017; Trosko 2017). The TKCs characterize an agent as follows: (1) Is electrophilic or can be metabolically activated; (2) Is genotoxic; (3) Alters DNA repair or causes genomic instability; (4) Induces epigenetic alterations; (5) Induces oxidative stress; (6) Induces chronic inflammation; (7) Is immunosuppressive; (8) Modulates receptor-mediated effects; (9) Causes immortalization; 10) Alters cell proliferation, cell death, or nutrient supply. It is striking that neither IARC nor the Smith et al. paper (2016) overtly mentions the problem of species-specific xenobiotic metabolism. 
Given the high doses routinely applied in toxicology studies (Buckley and Dorato 2009; Smith and Perfetti 2020), tens of thousands of chemicals and pharmaceuticals currently in commerce would be expected to display a positive finding in one or more of the TKCs (IARC 2017). This is especially true in light of the fact that many in vivo studies employ a non-physiological route of administration (e.g., intraperitoneal).

\section{Protocols for cancer hazard assessment of chemicals represent older technologies}

Many of the procedures underlying the standard protocols for the assessment of the carcinogenic potential of chemicals were developed many decades ago. The rodent cancer bioassay utilizing mice and rats was developed in the 1960s (Cohen 2010a, b). Ames and his colleagues invented the eponymous Ames Test in the early 1970s (Ames et al. 1972; 1973a, b; McCann et al. 1975). While chromosome aberrations had been observed for over 100 years, Moorhead et al. developed the in vitro chromosome aberrations test in 1960 (Evan 1976; Natarajan 2002). In 1970, Boller and Schmid developed a test method to evaluate the frequency of micronucleated erythrocytes found among normal erythrocytes. This initial method used bone marrow and peripheral blood cells from the Chinese hamster following treatment with the strong alkylating agent, trenimon. Boller and Schmid (1970) termed this method the "Mikrokern-Test (micronucleus test)". During the early to mid-1970's Schmid (1975) and Heddle's group (1973) further developed the protocols for conducting the micronucleus test.

In contrast with the older technologies currently employed in the assessment of the carcinogenic potential of chemicals, clinical oncology is leveraging an ever-improving understanding of the pathogenesis of cancer to bring new technologies to patients.

\section{Increased mechanistic specificity is driving clinical oncology}

Historically, once a cancer grew to a size sufficient to produce symptoms (Gospodarowicz et al. 1998; American Joint Committee on Cancer 2017), or intentional (Greene 2016) or serendipitous screening detected a tumor, it was staged thus defining its clinical extent (American Joint Committee on Cancer 2017) and graded for cellular changes related to the degree of differentiation (Horne 1992; Liu and Wu 2020). Many professional bodies, including the College of American Pathologists (CAP.org), have often internationally agreed to Cancer Protocols for reporting cancers (biopsies, resections). They include up-to-date requirements including additional testing that is needed for each type of cancer (Renshaw et al. 2018). As mechanistic understanding of human cancers progressed, an additional step of testing for the presence of specific genetic changes, found in only a subset of the patients presenting with that tumor type, could be conducted (USDHHS 2021). The presence or absence of these additional genetic markers guided the oncologist in the selection of the chemotherapy, immunotherapy, or surgical protocol with the highest probability of efficacy for the patient with that particular gross histological and molecular profile (CDC 2019). The tremendous activity directed toward the identification of specific molecular alterations in human cancers can be seen in the large number of relatively new cancer drugs targeting specific mutations or pathways that have been brought to market in the last 20 years (Table 1, Supplemental Materials).

\section{Cancer hazard assessment of new chemicals should strive for specificity}

Genetic changes are the foundation for the development of cancer, with multiple errors in a single cell necessary for cancer development (Shen and Laird 2013). These genetic changes can be inherited, can occur due to direct DNA damage (DNA reactivity), or secondary to spontaneous errors occurring during normal DNA replication. The degree of correlation between the genotoxicity test results or rodent tumor data and human cancer risk cannot be determined (Berry 2017; Smith et al. 2019). The main reason these in vitro genotoxicity tests can be misleading is because of the many assumptions made in interpreting positive results and built-in technical limitations of each assay. Specifically, in some of these assays, the presence or absence of a cellular protein for the gene can be due to a mutation or to an alteration in the expression of that gene (Trosko 2010; Trosko and Upham, 2010). Another concept that is ignored in a genotoxicity assay is that not all mutations are due to DNA damage that persists unrepaired, as in the skin-cancer prone human hereditary syndromes of xeroderma pigmentosum. In other words, while feeble genomic DNA repair after exposure to ultraviolet light is the very best example that mutations are correlated with repair defects, in all likelihood, errors of DNA replication of normal genomic DNA are the cause of most mutations in human cells (Loeb 2011; Tomasetti et al. 2017).

A further major source of contention is, what are the target cells that are altered and then progress to become the ultimate "cancer stem cells"? Human organ-specific adult stem cells exist in almost all if not all organs (Reya, 2001; Visvader and Lindeman 2012; Kreso and Dick 2014; Dawood et al. 2014; NIH 2016; Kuşoğlu and Biray Avcı 2019). These organ-specific stem cells have few mitochondria, whereas 
their terminally differentiated offspring contain many (Payandeh et al. 2020). Stem cells metabolize via glycolysis and their differentiated daughters metabolize glucose via oxidative phosphorylation (Shyh-Chang et al. 2013). This is also why in vivo detection of DNA adducts is sometimes misleading because they can reflect a chemical's having damaged mitochondrial DNA in a progenitor (finite limited cell division cell) and terminally differentiated cells (Vitale et al. 2017). It has been proposed that the progenitor cells are not going to give rise to cancer (Trosko 2009).

This also raises a challenge to the idea that one of the characteristics of a carcinogen is its ability to induce immortalization. Conceptually, a stem cell is naturally immortal until it is induced by epigenetic mechanisms to differentiate or become mortal. Initiation is best described as the first step in the multi-step, multi-mechanism process of carcinogenesis. A normal, naturally immortal stem cell is unable to remain immortal because, during its differentiation, some event is blocked in an essentially irreversible manner. However as a result of an 'initiation event,' it can now clonally multiply without terminal differentiation (Trosko 2018).

An illustrative example of the attempt to better model the early mutational events in cancer pathogenesis was the collaborative development by the Eleanor Roosevelt Institute for Cancer Research, Colorado State University, and Geisel School of Medicine at Dartmouth of the human-hamster hybrid $\mathrm{CHO} A(\mathrm{~L})$ assay (AL assay) with embryonic chick cell co-cultivation for metabolic activation (Collins et al. 1982; Waldren, 1983; Preston et al., 1991; Waldren et al. 1999; Gustafson et al. 2000). The Chinese hamster ovary cell line $\mathrm{CHO} \mathrm{A}(\mathrm{L})$ that stably incorporates human chromosome 11 is described by Ross et al. (2007).

The AL assay models the initial mutation in human cancer in the following ways: (1) chemicals tested must pass through two intact biological membranes, that is, the $\mathrm{CHO}$ cell membrane and embryonic chick hepatocyte membrane; (2) rat liver S9 normally used for metabolic activation is itself mutagenic in the AL assay, while embryonic chick cells provide an intact cellular metabolic activation system; (3) the mutagenicity target in the AL assay is human chromosome 11 ; (4) mutagenicity is measured via loss of cell surface markers lost due to mutational damage at specific, identifiable places on human chromosome 11, thereby reducing measurement artifacts, and (5) mutations of any size from base changes to large chromosomal deletions are detected and quantified. The system can be automated with cell counting by multicolor flow cytometry (McNiel 2000a, b; Zhou et al. 2006). While pointing in the correct conceptual direction, the AL assay is not practical as a screening tool for large numbers of chemicals because it is labor-intensive and relatively expensive.

While the degree of mechanistic specificity in chemical hazard assessment screening protocols would not be expected to reach the level seen in clinical oncology (Table 1, Supplemental Materials), an increased appreciation of the role played by particular Modes of Action (MOA) in the induction of certain important carcinomas is needed (Cohen et al. 2020). Examples of such work are the publications of the International Programme of Chemical Safety (IPCS) MOA framework in 2001 and the development by the International Life Sciences Institute Risk Science Institute (ILSI RSI) of a Human Cancer Relevance Framework. IPCS has combined and extended these components to produce a unified Human Cancer Relevance Framework (IPCS HRF) (Sonich-Mullin et al. 2001; Meek et al. 2003; Seed et al., 2005; Boobis et al. 2006; 2008).

The particularly important role played by post-initiating events in the development of human carcinomas is demonstrated by the case of the archetypal initiating agent, i.e., ionizing radiation. Japanese atomic bomb survivors have been followed in the Life Span Study (LSS) for decades. Despite being exposed to a strong burst of ionizing radiation expected to induce a significant number of mutations, of 22,538 incidences of first primary solid cancer cases identified in the LSS population, only $4.4 \%(992 / 22,538) * 100=4.4 \%)$ was associated with radiation exposure (Grant et al. 2017) (Fig. 1). In a previous report on this same LSS population, about 440 of 9335 of the deaths due to solid cancers $(4.7 \%)$ were attributed to radiation exposure (Preston et al. 2003). Therefore, radiation exposure is associated with $4-5 \%$ of cancer incidence and death (Preston et al. 2003; Grant et al. 2015, 2017). This result suggests that factors other than ionizing radiation-induction of point mutations are playing an important role in the development of human cancers. One possibility is a role for caloric restriction, and the Japanese diet, in the modification of risks for cancer before and shortly after the atomic bomb exposures. Caloric restriction is a well-known reducer of many chronic diseases (Golbidi et al. 2017; Rizza et al. 2013; Anton and Leeuwenburgh 2013; Omodei and Fontana 2011; Dirks and Leeuwenburgh 2006).

The unique Japanese diet, before and shortly after the acute exposures to radiation, was characterized by a low caloric level, reliance upon vegetables, raw fish, soy products, green tea, and rice, with no meat. Keeping in mind, historically at that time, the stature and breast cancer frequency in Japanese women was very low. Today, because of the shift in the Japanese diet toward a more Western diet, the frequency of breast cancer in Japanese women is approaching that of the frequencies of Western women (Hirose et al. 2003). 
Fig. 1 Incidence of cases of solid cancers in Japanese atomic bomb survivors 1958-2009

\section{Incidence of Cases of Solid Cancers in Japanese Atomic Bomb Survivors 1958-2009}

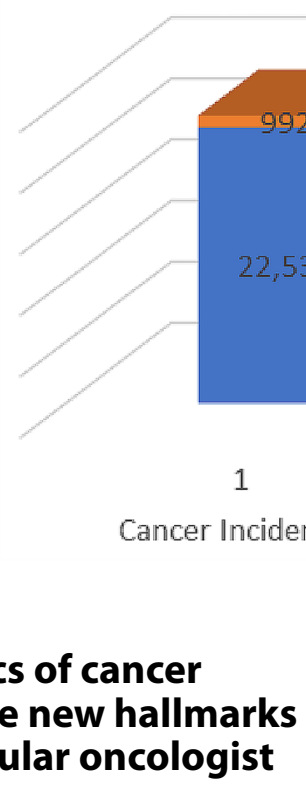

If one is to try to identify characteristics of an agent (microbiological, physical, chemical, etc.) that might contribute to the multi-stage, multi-mechanism pathogenesis of cancer, then one must not only seek specificity in one set (e.g., the TKCs), but also with others (e.g., the NHC), in the end, different conceptualizations should be compatible with one another as to consistency and plausibility. Given the criticisms regarding some characteristics of the TKCs, examinations of the misleading Hallmarks must be treated similarly. In their updated Hallmarks of Cancer, Hanahan and Weinberg, (2011) conceptualized these characteristics.

Examination of the characteristics of the hallmarks of cancer demonstrates that they are not unique to cancer cells, but can be intrinsic to normal adult organ-specific stem cells.

Hanahan and Weinberg (2011) have provided evidence for the stem cell hypothesis of cancer and that the normal, immortal adult stem cell, once blocked from terminal differentiation remains immortal and is not induced to mortality. Normal stem cells are resistant to agents that can damage genomic DNA (Vitale et al. 2017). These normal adult stem cells can invade other tissues/organs during development, as cancer stem cells. These normal adult organ-specific stem cells also can induce angiogenesis. Apparently, these adult organ-specific stem cells are susceptible to either differentiation or apoptosis-inducing agents (Vitale et al. 2017).

Knowing the Mode of Action of a non-DNA reactive chemical is extremely important. Only if one understands the total context of the user's exposure, can a cautious decision be made. In all likelihood, the pharmaceutical industry has thrown out thousands of potentially efficacious drugs based on not taking into account this complex context.

Seeing the non-specifics in both of these attempts to provide generalized concepts for determining "carcinogenicity" of any agent associated with cancer appearing after exposure, calls for a reevaluation. Hanahan and Weinberg, have stated:

"Some would argue that the search for the origin and treatment of this disease will continue over the next quarter century in much the same manner as it has in the recent past, by adding further layers of complexity to the scientific literature that is already complex almost beyond measure. But we anticipate otherwise: those researching the cancer problem will be practicing a dramatically different type of science than we have experienced over the past 25 years. Surely much of this change will be apparent at the technical level. But ultimately, the more fundamental change will be conceptual. "(Hanahan and Weinberg, 2010.)

The determination of any agent associated with a cancer has to be viewed as to its mechanistic role as either (a) a mutagen (error of DNA repair of genomic DNA or error of DNA replication of normal adult organ-specific stem cells); (b) a cytotoxicant (a necrotic cytotoxicant, an apoptosis inducer or blocker, an autophagy-inducer, a cell removal via injury or surgery to cause compensatory hyperplasia or; (c) an epigenetic agent that inappropriately alters gene expression at threshold levels. The search for simple categorizations of agents that might contribute to the appearance of a cancer will likely not be fruitful. 


\section{Conclusions}

The ten key characteristics of human cancer are too broad and non-specific to be useful as a protocol for evaluating the potential cancer hazard of chemicals. Extremely high false-positive rates might communicate to the public the false notion that everything is a carcinogen. As knowledge regarding the causation and progression of human cancers increases, this should be applied to the development of increasingly relevant testing protocols for the identification of potential human carcinogens, with particular emphasis on dose-response relationships.

Supplementary Information The online version contains supplementary material available at https://doi.org/10.1007/s00204-021-03109-w.

Author contributions CJS, TAP, AWH, and SCB prepared an initial draft. CJS, TAP, AWH, SCB, JET, JAK, JIG, DEB, CGB, and AD added additional text, concepts, refined interpretations of the literature, and added a significant number of references.

Funding The authors did not receive funds, Grants, or support from any organization for the submitted work.

\section{Declarations}

Conflict of interest The authors declare that they have no conflict of interest.

\section{References}

American Joint Committee on Cancer (AJCC) (2017) Lung. AJCC Cancer Staging Manual, 8th edn. Springer, New York, pp 431-456

Ames BN, Gurney EG, Miller JA, Bartsch H (1972) Carcinogens as frameshift mutagens: metabolites and derivatives of 2-acetylaminofluorene and other aromatic amine carcinogens. Proc Natl Acad Sci USA 69(11):3128-3132. https://doi.org/10.1073/pnas. 69.11.3128

Ames BN, Durston WE, Yamasaki E, Lee FD (1973a) Carcinogens are mutagens: a simple test system combining liver homogenates for activation and bacteria for detection. Proc Natl Acad Sci USA 70(8):2281-2285. https://doi.org/10.1073/pnas.70.8.2281

Ames BN, Lee FD, Durston WE (1973b) An improved bacterial test system for the detection and classification of mutagens and carcinogens. Proc Natl Acad Sci USA 70(3):782-786. https://doi.org/ 10.1073/pnas.70.3.782

Anton S, Leeuwenburgh C (2013) Fasting or caloric restriction for healthy aging. Exp Gerontol 48(10):1003-1005

Berry C (2017) The failure of rodent carcinogenesis as a model for man. Toxicol Res (camb) 7(4):553-557. https://doi.org/10.1039/ c7tx00283a

Boller K, Schmid W (1970) Chemische mutagenese beim sauger. Das knochenmark des Chinesischen hamsters als in vivo-test system. Haematologische befunde nach Behandlung mit Trenimon. Humangenetik 11:35-54

Boobis AR, Cohen SM, Dellarco V, McGregor D, Meek ME, Vickers C, Wilcocks D, Farland W (2006) IPCS framework for analyzing the relevance of a cancer mode of action for humans. Crit
Rev Toxicol 36(10):781-792. https://doi.org/10.1080/10408 440600977677

Boobis AR, Doe JE, Heinrich-Hirsche B, Meek ME, Munn S, Ruchirawat M, Schlatter J, Seed J, Vickers C (2008) IPCS framework for analyzing the relevance of a non-cancer mode of action for humans. Crit Rev Toxicol 38:87-96

Buckley LA, Dorato MA (2009) High dose selection in general toxicity studies for drug development: a pharmaceutical industry perspective. Regul Toxicol Pharmacol 54(3):301-307. https:// doi.org/10.1016/j.yrtph.2009.05.015

Bus JS (2017) IARC use of oxidative stress as key mode of action characteristic for facilitating cancer classification: glyphosate case example illustrating a lack of robustness in interpretative implementation. Regul Toxicol Pharmacol 86:157-166. https:// doi.org/10.1016/j.yrtph.2017.03.004

Centers for Disease Control and Prevention (CDC), Office of the Associate Director for Science (OADS), Genomics \& Precision Public Health, Genomics and Precision Health, Hereditary Breast and Ovarian Cancer, Genetic testing, Genetic testing for hereditary breast and ovarian cancer (2019) https://www. cdc.gov/genomics/disease/breast_ovarian_cancer/testing.htm. Accessed 28 March 2021.

Cohen SM (2010a) An enhanced 13-week bioassay: an alternative to the 2-year bioassay to screen for human carcinogenesis. Exp Toxicol Pathol 62:497-502

Cohen SM (2010b) Evaluation of possible carcinogenic risk to humans based on liver tumors in rodent assays: the 2-year bioassay is no longer necessary. Toxicol Pathol 38:487-501

Cohen SM, Zhongyu Y, Bus JS (2020) Relevance of mouse lung tumors to human risk assessment. J Toxicol Environ Health Part B 23(5):214-241. https://doi.org/10.1080/10937404.2020. 1763879

Collins A, Jones C, Waldren CA (1982) A survey of DNA repair incision activities after ultraviolet irradiation of a range of human, hamster, and hamster-human hybrid cell lines. J Cell Sci $56: 423-440$

Dawood S, Austin L, Cristofanilli M (2014) Cancer stem cells: implications for cancer therapy. Oncol (willist Park) 28(12):1101-1107

Dirks AJ, Leeuwenburgh C (2006) Caloric restriction in humans: potential pitfalls and health concerns. Mech Ageing Dev 127(1):1-7

Evans HJ (1976) Cytological methods for detecting chemical mutagens. In: Hollaender A (ed) Chemical mutagens, principles and methods for their detection, vol 4. Plenum Press, New York and London, pp 1-29

Golbidi S, Daiber A, Korac B et al (2017) Health benefits of fasting and caloric restriction. Curr Diab Rep 17(12):123

Gospodarowicz M, Benedet L, Hutter RV, Fleming I, Henson DE, Sobin LH (1998) History and international developments in cancer staging. Cancer Prev Control 2(6):262-268

Grant EJ, Ozasa K, Ban N, de Gonzalez AB, Cologne JB, Cullings HM, Doi K, Furukawa K, Imaoka T, Kodama K, Nakamura N, Niwa O, Preston DL, Rajaraman P, Sadakane A, Saigusa S, Sakata R, Sobue T, Sugiyama H, Ullrich RL, Wakeford R, Yasumura S, Milder C, Shore RE (2015) A report from the 2013 International Symposium: The evaluation of the effects of low-dose radiation exposure in the life span study of atomic bomb survivors and other similar studies. Health Phys 108(5):551-556

Grant EJ, Brenner A, Sugiyama H, Sakata R, Sadakane A, Utada M, Cahoon EK, Milder CM, Soda M, Cullings HM, Preston DL, Mabuchi K, Ozasa K (2017) Solid cancer incidence among the life span study of atomic bomb survivors: 1958-2009. Radiat Res 187(5):513-537. https://doi.org/10.1667/RR14492.1

Greene H (2016) Cancer prevention, screening, and early detection. Chapter 1 In: Gobel BH, Triest-Robertson S, Vogel WH (eds) Advanced oncology nursing certification review and resource 
manual 2nd edn. Oncology Nursing Society, Textbook Binding, Pittsburgh, pp 1-27.

Gustafson DL, Franz HR, Ueno AM (2000) Vanillin (3-methoxy4-hydroxybenzaldehyde) inhibits mutation induced by hydrogen peroxide, $\mathrm{N}$-methyl-N-nitrosoguanidine (MNNG) and mitomycin $\mathrm{C}$ but not 137Cs $\gamma$-radiation at the CD59 locus in human-hamster hybrid AL cells. Mutagenesis 15(3):207-213

Hanahan D, Weinberg RA (2011) Hallmarks of cancer: the next generation. Cell 5:646-674. https://doi.org/10.1016/j.cell.2011.02.013

Heddle JA (1973) A rapid in vivo test for chromosomal damage. Mutat Res 18:187-190

Hirose K, Takezaki T, Hamajima N, Miura S, Tajima K (2003) Dietary factors protective against breast cancer in Japanese premenopausal and postmenopausal women. Int J Cancer 107:276-282

Horne R (1992) Cancer differentiation and de-differentiation. Chapter 13. In: Horne R (ed) Health and survival in the 21st century, HarperCollins Publishers Pty Limited, pp 118-119.

National Institutes of Health (NIH) Stem Cell Information Home Page (2016) Stem Cell Information, Bethesda, MD: National Institutes of Health, U.S. Department of Health and Human Services (2016) http://stemcells.nih.gov/info/2001report/chapter4.htm Accessed 1 May 2021.

US Department of Health and Human Services (USDHHS), National Institutes of Health, National Cancer Institute, About Cancer, Cancer Causes and Prevention, Genetics (2021) Genetic testing for inherited cancer susceptibility syndromes. https://www.cancer. gov/about-cancer/causes-prevention/genetics/genetic-testing-factsheet\#what-is-genetic-testing, Accessed 28 March 2021.

International Agency for Research on Cancer (IARC) (2017) Some organophosphate insecticides and herbicides, Volume 112, IARC monographs on the evaluation of carcinogenic risks to humans, Lyon, France

Kreso A, Dick JE (2014) Evolution of the cancer stem cell model. Cell Stem Cell 14:275-291

Kuşoğlu A, Biray AÇ (2019) Cancer stem cells: a brief review of the current status. Gene 681:80-85. https://doi.org/10.1016/j.gene. 2018.09.052

Liu D, Wu Y (2020) Association of an anaplastic lymphoma kinase pathway signature with cell de-differentiation, neoadjuvant chemotherapy response, and recurrence risk in breast cancer. Cancer Commun 40(9):422-434. https://doi.org/10.1002/cac2.12038

Loeb L (2011) Human cancers express mutator phenotypes: origin, consequences and targeting. Nat Rev Cancer 11:450-457. https:// doi.org/10.1038/nrc3063

McCann J, Spingarn NE, Kobori J, Ames BN (1975) Detection of carcinogens as mutagens: bacterial tester strains with $\mathrm{R}$ factor plasmids. Proc Natl Acad Sci USA 72(3):979-983. https://doi. org/10.1073/pnas.72.3.979

McNiel EA (2000a) Evaluation of feline rabies vaccines for mutagenicity using the AL Assay. In: Proceedings of 90th Annual Meeting of the American Association for Cancer Research, pp 509.

McNiel EA (2000b) Vaccine-associated carcinogenesis in cats, Dissertation, Colorado State University.

Meek ME, Bucher JR, Cohen SM, Dellarco V, Hill RN, LehmanMcKeeman LD, Longfellow DG, Pastoor T, Seed J, Patton DE (2003) A framework for human relevance analysis of information on carcinogenic modes of action. Crit Rev Toxicol 33(6):591-653. https://doi.org/10.1080/713608373

Moorhead PS, Noweel PC, Mellman WJ, Battips DM, Hungerford DA (1960) Chromosome preparation of leukocytes cultured from human peripheric blood. Exp Cell Res 20:613-616

Natarajan AT (2002) Chromosome aberration: past, present and future. Mutat Res 504(1-2):3-16

Omodei D, Fontana L (2011) Calorie restriction and prevention of age-associated chronic disease. FEBS Lett 585(11):1537-1542
Payandeh Z, Tazehkand AP, Barati G, Pouremamali F, Kahroba H, Baradaran B, Samadi N (2020) Role of Nrf2 and mitochondria in cancer stem cells; in carcinogenesis, tumor progression, and chemoresistance. Biochimie 179:32-45. https://doi.org/10. 1016/j.biochi.2020.09.014

Preston DL, Shimizu Y, Pierce DA, Suyama A, Mabuchi K, Ritenour ER, Braaton M, Harrison GH, Ueno A, Gadd M, MancoJohnson M, Parker R, Shih S, Waldren CA (1991) Absence of mutagenic effects of continuous and pulsed ultrasound in cultured (AL) human-hamster hybrid cells. Ultrasound Med Biol 17(9):921-930

Preston DL, Shimizu Y, Pierce DA, Suyama A, Mabuchi K (2003) Studies of mortality of atomic bomb survivors. Report 13: Solid cancer and noncancer disease mortality: 1950-1997. Radiat Res 160(4):381-407. https://doi.org/10.1667/rr3049

Renshaw AA, Mena-Allauca M, Gould EW, Sirintrapun SJ (2018) Synoptic reporting: evidence-based review and future directions JCO Clinical. Cancer Inform 2:1-9. https://doi.org/10.1200/CCI. 17.00088

Reya $\mathrm{T}$ et al (2001) Stem cells, cancer, and cancer stem cells. Nature 414:105-111

Rizza W, Veronese N, Fontana L (2013) What are the roles of calorie restriction and diet quality in promoting healthy longevity? Ageing Res Rev 13:38-45. https://doi.org/10.1016/j.arr.2013.11.002

Ross CD, French CT, Keysar SB, Fox MH (2007) Mutant spectra of irradiated $\mathrm{CHO}$ AL cells determined with multiple markers analyzed by flow cytometry. Mutat Res 624(1-2):61-70. https://doi. org/10.1016/j.mrfmmm.2007.04.005

Schmid W (1975) The micronucleus test. Mutat Res 31:9-15

Seed J, Carney E, Corley ER, Crofton K, DeSesso J, Foster P, Kavlock R, Kimmel G, Klaunig J, Meeik E, Preston J, Slikker W, Tabacova S, Williams G (2005) Overview: using mode of action and life stage information to evaluate the human relevance of animal toxicity data. Crit Rev Toxicol 35:663-672

Shen H, Laird PW (2013) Interplay between the cancer genome and epigenome. Cell 153:38-55

Shyh-Chang N, Daley GQ, Cantley LC (2013) Stem cell metabolism in tissue development and aging. Development 140(12):2535-2547. https://doi.org/10.1242/dev.091777

Smith CJ, Perfetti TA (2020) High-dose exposure to synthetic chemicals, hormones, or homeostatic substances in experimental animals or humans can induce artefactual pathology. Toxicol Res Appl 4:1-9. https://doi.org/10.1177/2397847320940557

Smith MT, Guyton KZ, Gibbons CF, Fritz JM, Portier CJ, Rusyn I, DeMarini DM, Caldwell JC, Kavlock RJ, Lambert PF, Hecht SS, Bucher JR, Stewart BW, Baan RA, Cogliano VJ, Straif K (2016) Key characteristics of carcinogens as a basis for organizing data on mechanisms of carcinogenesis. Environ Health Perspect 124(6):713-721. https://doi.org/10.1289/ehp.1509912

Smith CJ, Perfetti TA, King JA (2019) Rodent 2-year cancer bioassays and in vitro and in vivo genotoxicity tests insufficiently predict risk or model development of human carcinomas. Toxicol Res Appl 3:1-19. https://doi.org/10.1177/2397847319849648

Sonich-Mullin C, Fielder R, Wiltse J, Baetcke K, Dempsey J, FennerCrisp P, Grant D, Hartley M, Knaap A, Kroese D et al (2001) IPCS conceptual framework for evaluating a mode of action for chemical carcinogenesis. Regul Toxicol Pharmacol 34(2):146152. https://doi.org/10.1006/rtph.2001.1493

Tomasetti C, Li L, Vogelstein B (2017) Stem cell divisions, somatic mutations, cancer etiology, and cancer prevention. Science 355(6331):1330-1334. https://doi.org/10.1126/science.aaf9011

Trosko JE (2009) Cancer: a stem cell-based disease? In: Dittmar $\mathrm{T}$, Zanker K (eds) Stem cell biology in health and disease. Springer, Dordrecht, pp 185-222. https://doi.org/10.1007/ 978-90-481-3040-5 9 
Trosko JE (2010) Commentary on toxicity testing in the 21st century: a vision and a strategy: stem cells and cell-cell communication as fundamental targets in assessing the potential toxicity of chemicals. Hum Exp Toxicol 29(1):21-29. https://doi.org/10.1177/ 0960327109354663

Trosko JE (2017) Reflections on the use of 10 IARC carcinogenic characteristics for an objective approach to identifying and organizing results from certain mechanistic studies. Toxicol Res Appl 1:1-10. https://doi.org/10.1177/2397847317710837

Trosko JE (2018) Mechanisms of epigenetic toxicity in the pathogenesis of cancer for precision medicine. J Cancer Treat Diagnosis 2(6): $17-29$

Trosko JE, Upham BL (2010) A paradigm shift is required for the risk assessment of potential human health after exposure to low-level chemical exposures: a response to the toxicity testing in the $21 \mathrm{st}$ century report. Int J Toxicol 29(4):344-357. https://doi.org/10. $1177 / 1091581810371384$

Visvader JE, Lindeman GJ (2012) Cancer stem cells: current status and evolving complexities. Cell Stem Cell 10:717-728

Vitale I, Manic G, De Maria R, Kroemer G, Galluzzi L (2017) DNA damage in stem cells. Mol Cell 66:306-319. https://doi.org/10. 1016/j.molcel.2017.04.006
Waldren CA (1983) Mutational analysis in cultured humanhamster hybrid cells. In: de Serres FJ (ed) Chemical mutagens. Springer, Boston, pp 235-260. https://doi.org/10.1007/ 978-1-4613-3694-5 8

Waldren CA, Ueno AM, Schaeffer BK (1999) Mutant yields and mutational spectra of the heterocyclic amines MeIQ and PhIP at the S1 locus of human-hamster AL cells with activation by chick embryo liver (CELC) co-cultures. Mutat Res 425(1):29-46

Zhou H, Xu A, Gillispie JA (2006) Quantification of CD59- mutants in human-hamster hybrid (AL) cells by flow cytometry. Mutat Res 594(1-2):113-119

Publisher's Note Springer Nature remains neutral with regard to jurisdictional claims in published maps and institutional affiliations. 